Original Article

DOI: $10.19027 /$ jai.15.2.92-100

\title{
Efficacy of whole cell vaccine Aeromonas hydrophila on catfish broodstock and it's offspring resistance againt motile aeromonad septicemia (MAS)
}

\author{
Efikasi vaksin sel utuh Aeromonas hydrophila pada induk lele \\ Clarias gariepinus dalam meningkatkan ketahanan benih terhadap \\ motil aeromonad septicemia (MAS)
}

\author{
Sukenda*, Kiki Amalia Pratiwi, Rahman, Dendi Hidayatullah \\ Departemen Budidaya Perairan, Fakultas Perikanan dan Ilmu Kelautan, Institut Pertanian Bogor \\ Kampus IPB Dramaga Bogor, Jawa Barat 16680 \\ *E-mail: sukenda67@gmail.com
}

\begin{abstract}
Transfer of maternal immunity by mean of passive immunization is a way to deliver protection and durability of antibodies on the offspring. The purpose of this research was to analize the efficacy of Aeromonas hydrophila vaccine on the catfish broodstock to maternal transfer of immunity, and offspring resistance. The average body weight of broodstock used in this study were $650 \pm 50 \mathrm{~g}$ were kept in tarpaulin sized $2 \times 1 \times 0.5 \mathrm{~m}^{3}$. This study used a randomized complete design with two treatments and three replications. Female broodstock were vaccinated using intraperitonial injections at a dose $0.4 \mathrm{~mL} / \mathrm{kg}$ and control fish were injected with phospate buffered saline (PBS). The observed parameters include haematology of broodstock, mortality, the relative percent survival, and antibody titers in broodstock, eggs, and offspring. Vaccination on broodstock catfish delivers a significant antibody level $(\mathrm{P}<0.05)$ on offspring compared to control catfish with relative percent survival of offspring at 5, 10, and 15 days after hatching were $67.76 \%, 82.66 \%$, and $71.66 \%$ respectively.
\end{abstract}

Keywords: catfish, Aeromonas hydrophila, vaccination, antibody transfer

\begin{abstract}
ABSTRAK
Transfer kekebalan dari induk kepada benih melalui imunisasi pasif merupakan salah satu cara untuk memberikan proteksi pada benih. Tujuan penelitian ini untuk menguji efikasi vaksin sel utuh Aeromonas hydrophila pada induk ikan nila dalam mentransfer kekebalan spesifik ke benih dan menguji ketahanan benih hasil pemijahan induk yang divaksin. Induk lele yang digunakan pada penelitian ini memiliki bobot rata-rata $650 \pm 50 \mathrm{~g}$ dipelihara di kolam terpal berukuran $2 \times 1 \times 0,5 \mathrm{~m}^{3}$. Penelitian ini menggunakan rancangan acak lengkap dengan dua perlakuan dan tiga ulangan. Induk betina lele divaksinasi secara intraperitonial dengan dosis $0,4 \mathrm{~mL} / \mathrm{kg}$ ikan dan induk lele kontrol disuntik dengan phospate buffer saline (PBS). Parameter yang diamati meliputi hematologi induk, mortalitas, tingkat kelangsungan hidup relatif benih, dan titer antibodi. Vaksinasi induk lele memberikan hasil level antibodi yang signifikan $(\mathrm{P}<0,05)$ pada induk, telur, dan benih lele dibandingkan perlakuan kontrol dengan tingkat kelangsungan hidup relatif benih umur 5, 10, dan 15 hari pacatetas masing-masing sebesar 67,76\%; 82,66\%; dan $71,66 \%$.
\end{abstract}

Kata kunci: ikan lele, Aeromonas hydrophila, vaksinasi, transfer antibodi

\section{INTRODUCTION}

Juvenile is referred an individual organism that has not yet reached its adult form, sexual maturity or size. Indeed, it is a developmental stage that is not only important but also critical due to the exposure to high vulnerable elements such as diseases. a disease that is well known in catfish farming, especially juvenile, is motile aeromonad septicemia (MAS), which is caused by a bacterial infection named Aeromonas hydrophila (Fernandez et al., 2014).

A. hydrophila is an opportunistic bacteria mostly found in fresh and brackishwater environment. It is an opportunistic bacteria as it often arises once the fish is in a stress condition 
and is also virulent, especially on catfish, due to its ability to cause more than $60 \%$ mortality within seven days (Pramudita et al., 2013).

According to Ghenghesh et al. (2008), Aeromonas sp. lives at an optimum temperature of $22-35{ }^{\circ} \mathrm{C}$, and most of the bacteria in the mentioned group are able to live at temperature ranging between $0-45{ }^{\circ} \mathrm{C}$ with an optimum $\mathrm{pH}$ ranging between 5.5-9.0. Aeromonas sp. is characterized by features such as single polar flagellum, gram negative, and glucose fermentation ability.

Hemorrhage and death are among the clinical symptoms caused by $A$. hydrophila pathogen $(\mathrm{Fu}$ et al., 2014). Mulia and Purbomartono (2007) showed that the development of both internal and external symptoms due to A. hydrophila were as follows: non-active swimming, laziness, injuries in injection area, swollen abdomen, abdominal cavity containing yellowish liquid, yellowish intestine, flabby and pale kidney, swollen stomach filled with water, a dark red heart, and pale heart, gills, and intestines.

MAS disease was controlled (in early stage) using antibiotics that had negative effects, since it made A. hydrophila and other bacteria (in the environment) resistant to antibiotics and destroyed beneficial sensitive bacteria (Azhar, 2013). The use of antibiotics can lead to residue accumulation in fish, which can endanger consumer health (Wahjuningrum et al., 2010).

As a consequence, an alternative method to antibiotics was used in the present research to prevent MAS disease in juvenile catfish i.e. broodstock vaccination or maternal umminity transfer through broodstock vaccination (Zang et al., 2013). The use of vaccine did not generate residue accumulation in fish body, was not harmful to consumer health, and was environmentally friendly (Gudding et al., 2013). Maternal immunity transfer through vaccination is a way of protecting juvenile, since it reduces mortality due to diseases (Nisaa et al., 2016).

Previous research on vaccine administration using Streptococcus agalactiae in tilapia Oreochromis niloticus broodstock led to a transfer of maternal umminity in juvenile that protected against disease (Hidayatullah, 2016). Maternal immunity transfer research using intact $A$. hydrophila bacteria cell with formaline killed cell (FKC) method in catfish Clarias sp. through injection to broodstock to proctect juvenile has never been investigated. Thus, there is a need to evaluate the efficacy of intact
A. hydrophila cell vaccine in catfish broodstock in increasing the resistance of juvenile against A. hydrophila infection. The present research was aimed at analysing the efficacy of intact A. hydrophila bacteria cell vaccine in female catfish in transferring specific maternal immunity (antibody) to offspring and evaluate the resistance of juvenile that result from vaccinated broodstock

\section{MATERIALS AND METHODS}

\section{Preparation of broodstock ponds}

Two tarpaulin ponds $\left(2 \times 1 \times 0,5 \mathrm{~m}^{3}\right)$ were used in the present study for broodstock rearing. Ponds were first cleaned to remove remaining wastes that adhered to tarpaulin and feed from previous rearing. The ponds were then dried for $24 \mathrm{~h}$ and filled with water and a desinfectant (virkon) at a dose of $1.2 \mathrm{mg} / \mathrm{L}$. Ponds were finally ready after a $24 \mathrm{~h}$ resting period.

\section{Broodstock rearing}

Catfish broodstock in their second stage of gonad maturity were used in the present study (Nisaa et al., 2016). Female broodstock gonad maturity stage was determined through egg collecting method using catheter. Matured eggs will detach from other when touched. Only nine healthy broodstock reached the second stage of maturity out of a total of 30 that were reared.

\section{Broodstock stocking and maintenance}

Catfish broodstock were brought from a catfish farming ponds in Ciampea complex, Asri, Ciampea sub-district, Bogor. Six broodstock (three males and three females) at average body weight and length of $650 \pm 50 \mathrm{~g}$ and $43.5 \pm 5.5$ $\mathrm{cm}$, respectively, were stocked in each treatment (ponds). Afterwards, broodstock were transferred into tarpaulin ponds $\left(2 \times 1 \times 0.5 \mathrm{~m}^{3}\right)$ and male and female were reared separately. Broodstock were then acclimatised to environmental and feed conditions for two weeks. Broodstock were fed twice daily ( $8.00 \mathrm{am}$ and $4.00 \mathrm{pm})$ at satiation on commercial feed (35\% protein). Water quality parameters such as temperature, $\mathrm{pH}$, dissolved oxygen, and total amonia nitrogen were $25-30{ }^{\circ} \mathrm{C}$, $6.5-8.5,>4 \mathrm{mg} / \mathrm{L}$, and $<0.01 \mathrm{mg} / \mathrm{L}$, respectively.

\section{Bacteria characterisation and increased virulence}

Bacteria characterization was performed to confirm that the bacteria to be used in the present study was pure $A$. hydrophila. the bacteria was 
isolated from organs such as fish kidney, liver, and wounds that were infected. The mediums were then incubated at $29-30{ }^{\circ} \mathrm{C}$ for $24 \mathrm{~h}$ and the grown bacteria was purified and re-characterized. Bacteria characterisation was done by mean of gram staining method, and biochemical test such as oxidative-fermentative (OF), motility, oxidase, and catalase, and bacterial validation through API 20 kit.

Increased virulence of bacteria was performed by mean of injecting $0.1 \mathrm{~mL}$ liquid culture $(A$. hydrophila bacteria) at a concentration of $10^{7} \mathrm{cfu} /$ $\mathrm{mL}$, intramuscularly to each of the healthy catfish. Injected fish were observed for clinical symptoms that indicate sickness of the test fish. Bacteria was then reisolated once a week on TSA medium.

\section{Vaccine preparation}

A. hydrophila bacterial inoculant, cultured on agar medium, was collected and aseptically cultured in TSB medium $(25 \mathrm{~mL})$ and incubated in water shaker at temperature of $29-30{ }^{\circ} \mathrm{C}$ and a speed of $140 \mathrm{rpm}$ for $24 \mathrm{~h}$ in order to obtain a bacterial concentration of $1.29 \times 109 \mathrm{cfu} / \mathrm{mL}$. Three percent of buffer neutral formaline (BNF) was added to the bacterial culture and incubated for $24 \mathrm{~h}$ in order to inactivate the bacteria. The incubated product was then centrifuged at 5,000 rpm for $30 \mathrm{~min}$ to separate the natant from the supernatant. The supernatant was disposed, while the granules from the centrifigation were cleaned twice using phosphate buffer saline (PBS) (first cleaning to dispose of the culture medium and second of the formalin). Afterwards, PBS was added to the granules according to the initial volume (Sugiani et al., 2013).

The viability of vaccine samples was evaluted by culturing the bacteria on TSA medium and incubated for $24 \mathrm{~h}$, aiming at preventing contamination of the pure vaccine that cause immunity reaction against pathogen and ensuring the bacteria cell used not active by observing the growth of bacterial colonies on TSA.

\section{Vaccination and spawning of broodstock}

Female broodstock were intraperitonially vaccinated at a dose of $0.4 \mathrm{~mL} / \mathrm{kg}$ and tagged in order to differentiate females in each treatment. Prior to vaccination, females were starved for 24 $\mathrm{h}$ and selected based on their health condition. Vaccinated female were reared until spawning.

Natural spawning was performed in the present study i.e. at $5.00 \mathrm{pm}$ spawning ponds were filled with water $(30 \mathrm{~cm})$ and equipped with aeration system at each side of the ponds. Afterwards, kakaban was used as substrate and placed at the bottom of the ponds. Males and females catfish were then placed into the ponds for spawning, which was performed four weeks post vaccination. Part of the fertilized eggs were sampled for antibody titer measurement.

\section{Hatching and juvenile rearing}

Eggs were incubated and hatched in tarpaulin ponds $\left(2 \times 1 \times 0.5 \mathrm{~m}^{3}\right)$ which were covered with paranet in order to maintain a temperature ranging between $29-31{ }^{\circ} \mathrm{C}$. During the rearing period, juvenile were first fed on frozen worm (after yolk absorbtion, from day-4 to day-15) and finally on commercial feed (powder) once they were over 15 days old. Juvenile were fed three times a day (08 am, $12 \mathrm{am}$, and $4 \mathrm{pm}$ ) at satiation.

\section{Juvenile challenge test}

Challenge test was performed to determine juvenile protection from vaccinated broodstock using juvenile of 5,10 , and 15 days old post hatching. Nine tanks were used with a diameter of $20 \mathrm{~cm}$ and water level of $15 \mathrm{~cm}$, and equipped with aeration stones in each treatments. Juvenile were stocked at a density of $20 \mathrm{fish} / \mathrm{tank}$, and a bacterial concentration of $10^{6} \mathrm{cfu} / \mathrm{mL}$ was used in the challenge test. Juvenile were immersed in the bacterial liquid for an hour, then placed into medium. Mortality was observed during 14 days.

\section{Test parameter}

Broodstock hematology was observed and involved parameters such as total erythrocyte $\left(\mathrm{cell} / \mathrm{mm}^{3}\right)$, total leukocyte $\left(\mathrm{cell} / \mathrm{mm}^{3}\right)$, hematocrit level (\%), haemoglobin level (\%), and antibody titer. Broodstock hematology observation was carried out two weeks post-vaccination. In addition, antibody titer parameter was noticed in eggs and juvenile (5, 10, and 15 days old). Mortality rate (MR) and relative percent survival (RPS) were checked post juvenile challenge test.

\section{Total erythrocyte}

Blood samples was sucked by mean of a pipette with a scale of 0.5 and added with Hayem's solution up to 101. Blood and Hayem's solution, in the pipette, were shacked to form a number eight until homogeneity, for 3-5 min. The first drop was disposed and the following were displayed on a haemocytometer, covered with a cover glass, and observed under microscope. The calculation was performed in five small box 
(haemocytometer). The formula used in total erythrocyte was as follows:

$$
\begin{aligned}
& \mathrm{RBC}\left(\text { cell } / \mathrm{mm}^{3}\right)= \\
& \frac{\text { counted cell } \times \text { dilution factor }}{\text { box volume }}
\end{aligned}
$$

\section{Total leukocyte}

Blood samples was sucked by mean of a pipette with a scale of 0.5 and added with Turk's solution up to a scale of 11. Blood and Turk's solution, in the pipette, were shacked to form a number eight until homogeneity, for 3-5 min. The first drop was disposed and the following were displayed on a haemocytometer, covered with a cover glass, and observed under microscope. Total leukocyte was determined in five small box (haemocytometer). The formula used was as follows:

$$
\begin{aligned}
& \text { WBC }\left(\text { cell } / \mathrm{mm}^{3}\right)= \\
& \frac{\text { counted cell } \times \text { dilution factor }}{\text { box volume }}
\end{aligned}
$$

\section{Hematocrit level}

Blood samples were placed into a hematocrit tube (up to $3 / 4$ of the tube volume), clogged with crystoceal, centrifuged at $3,000 \mathrm{rpm}$ for five min, and the precipitation length measured. The formula used to determine hematocrit level was as follows:

$$
\text { Hc }(\%)=\frac{\text { blood precipitation length }}{\text { total blood length }} \times 100
$$

\section{Haemoglobin level}

Haemoglobin level $(\mathrm{Hb})$ measurement was carried out through Sahli method that converts blood into hematic acid form (after chloride acid addition). Blood sample was sucked by mean of a Sahli pipette with up to a scale of $20 \mathrm{~mm}^{3}$ or 0.02 $\mathrm{mL}$, transferred into a $\mathrm{Hb}$-meter tube (previously filled with $\mathrm{HCl} 0.1 \mathrm{~N}$ up to a scale of 10), stirred and rested for 3-5 min. Afterwards, aquades was added until both blood and HCL colour becomes as the standard solution colour that is in the $\mathrm{Hb}$-meter. The scale was read by looking at the solution surface and matched with Sahli tube scale that could be seen on the scale track (yellow scale), signifying that the haemoglobin in $\mathrm{gr} / 100$ $\mathrm{mL}$ blood was high.

\section{Juvenile mortality rate (MR)}

Mortality rate is a comparison between the number of dead fish post-challenge test and the number of fish at the beginning of the test. MR was determined using the following formula:

$$
\operatorname{MR}(\%)=\mathrm{Nm} / \mathrm{No} \times 100
$$

Note:

$\mathrm{MR}=$ mortality rate $(\%)$

$\mathrm{Nm}=$ number of dead fish

No $=$ initial number of fish

\section{Relative percent survival of juvenile (RPS)}

The relative percent survival was calculated to determine juvenile protection post-challenge test and computed using the following formula:

$$
\operatorname{RPS}(\%)=[1-(\mathrm{Mv} / \mathrm{Mc})] \times 100
$$

\section{Note:}

RPS $=$ relative percent survival $(\%)$

$\mathrm{Mv}=$ mortality in juvenile from vaccinated broodstock (\%)

$\mathrm{Mc}=$ mortality in juvenile from control (\%)

\section{Antibody titer of broodstock, egg, and juvenile}

Antibody titer measurement was performed on broodstock blood plasma (post-vaccination), egg extract, juvenile body fluid (at 5, 10, and 15 days old). Broodstock blood plasma was collected on the vena caudal using a syringe, placed into a micro tube, and centrifuged at 3,000 rpm (for five min) until separation between blood and plasma occurred. Plasma was collected using micropipette and placed into an empty micro tube. The micro tube, containing the blood plasma, was incubated at $44{ }^{\circ} \mathrm{C}$ for $20 \mathrm{~min}$ to inactivate complements, and finally stored at $4{ }^{\circ} \mathrm{C}$ for antibody titer measurements.

Antibody titer measurement for egg extract was done by collecting 30 eggs, while in juvenile, it was performed by collecting five in each test. Both eggs and juvenile were cleaned with aquades, dried on using a filter paper, homogenised with $0.05 \%$ PBS-tween at a ratio of $1: 4(\mathrm{v} / \mathrm{v})$ by crashing, and finally centrifuged at 3,000 rpm for ten min. Centrifugation resulted in three layers i.e. first layer (fat), second layer (blood serum and body fluid that mixed with PBS), and third layer (egg shell and body tissue). The second layer was considered as blood serum and body fluid that were collected and the complement deactivated through heating method (at $47^{\circ} \mathrm{C}$ ), followed by antibody titer observation.

Antibody titer measurement was carried out through agglutination method using microtiter 
plate. PBS solution, $50 \mu \mathrm{L}$, was previously introduced in well number 2 up to well number 12. Blood serum, $50 \mu \mathrm{L}$, was also inserted in well number 1 as positive control. The measured serum will be introduced $(50 \mu \mathrm{L})$ in well number 2 and stirred to homogeneity using a micropipette. Series of dilutions were performed from well 2 up to well 11 and $50 \mu \mathrm{L}$ of the solution was disposed. $50 \mu \mathrm{L}$ of bacteria (concentration of $10^{9}$ cfu/mL) were added to each well (from 1 to 12 ) that were already mixed with serum and saline PBS. Microtiter plate was covered using a plastic wrap to avoid evaporation and incubated at 37 ${ }^{\circ} \mathrm{C}$ for $24 \mathrm{~h}$. Lumps (agglutination) like fog on the microtiter plate wells are positive results of antibody titer formation. Antibody value was shown based on the lowest dilution (still going through agglutination reaction).

\section{Data analysis}

Antibody titer parameters of broodstock, eggs, and juvenile $(5,10$, and 15 days old) were analyzed using independent-test analysis with an interval of confidence of 95\%, using SPSS 16.0. Data on juvenile mortality rate was analysed by mean of analysis of variance method (interval of confidence of 95\%), while relative percent survival (RPS) was analyzed descriptively.

\section{RESULTS AND DISCUSSION}

\section{Results}

\section{Broodstock hematological observation}

No significant differences $(\mathrm{P}>0.05)$ were observed among treatments in terms of broodstock hematologic parameters such as total erythrocyte, hematocrit, haemoglobin level, and hematocrit level. Meanwhile, total leukocyte and antibody titer signficantly differed among treatments $(\mathrm{P}<0.05)$. Data on broodstock hematology observation results and antibody titer are presented in Table 1 .

\section{Mortality rate and relative percent survival (RPS)}

Mortality rate (MR) of 5, 10, and 15 days old juvenile post challenge test showed significant differences between treatments $(\mathrm{P}<0.05)$. Control treatment had the highest MR compared to juvenile from vaccinated broodstock. Relative percent survival (RPS) of juvenile on day 5, 10 , and 15 of the challenge test were $67.76 \%$; $82.66 \%$; and $71.05 \%$, respectively. Juvenile MR and SRS observation data results post challenge test on day 5, 10, and 15 are presented in Table 2.

\section{Antibody titer of egg and juvenile}

Eggs and juvenile (5, 10, and 15 days old) antibody titer test observation results of vaccinated broodstock showed significant differences compared to control $(\mathrm{P}<0.05)$. However, juvenile antibody titer level decreased as the juvenile got older with the lowest values in control and 15 days old juvenile, being 2.00 and 3.33 respectively. Data on antibody titer test is presented in Table 3 .

\section{Discussion}

Bacterial diseases often attack freshwater fishes, for example catfish. Common freshwater disease is motile aeromonad septicemia (MAS), which is caused by A. hydrophila infection. It is able to cause high mortality in catfish in various stages, including juvenile stage. Vaccination is an effort to control A. hydrophila infection (Yi et al., 2014).

According to Swain and Nayak (2009), broodstock immunity and health status are of capital importance not only during spawning, but also for juvenile health. The maternal immunity that is transferred from broodstock become essential at the early developmental stage of juvenile, because embryo and juvenile could not well develop their immune response (Zapata et al., 2006). Fish health condition evaluation could be done by mean of blood profile dianogsis (Sayed \& Moneeb, 2015). Hematological observation in the present study was performed before and after vaccination with parameters such as total erythrocytes (RBC), total leukocyte (WBC), hematocrit, and haemoglobin concentration. Data on average total broodstock RBC ranged between $1.46-2.17 \times 10^{6}$ cell $/ \mathrm{mm}^{3}$ (Table 1) and showed value that were not significantly different among treatments $(\mathrm{P}>0.05)$. The total $\mathrm{RBC}$ was still within the normal range for healthy catfish as mentioned in Dopongtonung (2008) 1.05$3.0 \times 10^{6} \mathrm{cell} / \mathrm{mm}^{3}$.

Haemoglobin level is a parameter that displays RBC content in blood. The red color of blood is caused by the presence of haemoglobin that function in the transprot of oxygen and carbon dioxide and help in preventing high blood acidity. Data on average haemoglobin content ranged between 6.10-6.50 g\% (Table 1) and showed values that were not significantly different among treatments $(\mathrm{P}>0.05)$. Haemoglobin content in the present study was still within the normal range for healthy catfish i.e. 10.3-13.5 g\% (Dopongtonung, 2008). 
Table 1. Hematology and antibody titer of broodstock

\begin{tabular}{lcc}
\hline \multicolumn{1}{c}{ Parameter } & Control & Vaccine \\
\hline Erythrocyte $\left(\times 10^{6}\right.$ cell $\left./ \mathrm{mm}^{3}\right)$ & $2.17 \pm 0.24 \mathrm{a}$ & $1.46 \pm 0.10 \mathrm{a}$ \\
Leukocytes $\left(\times 10^{4}\right.$ cell $\left./ \mathrm{mm}^{3}\right)$ & $3.30 \pm 0.80 \mathrm{a}$ & $5.13 \pm 2.23 \mathrm{~b}$ \\
Haemoglobin $(\mathrm{g} \%)$ & $6.10 \pm 0.10 \mathrm{a}$ & $6.50 \pm 0.50 \mathrm{a}$ \\
Hematocrit $(\%)$ & $29.93 \pm 0.57 \mathrm{a}$ & $29.44 \pm 1.24 \mathrm{a}$ \\
Antibody titer $(-\log 2)$ & $3.00 \pm 0.00 \mathrm{a}$ & $5.66 \pm 0.57 \mathrm{~b}$ \\
\hline
\end{tabular}

Note: similar letter following the standard deviation value the mean values within the same row indicate no significant differences $(\mathrm{P}>0.05)$.

Table 2. Juvenile relative percent survival (RPS) afterchallenge test

\begin{tabular}{cccc}
\hline Juvenile challenge test (day) & Treatment & MR $(\%)$ & RPS $(\%)$ \\
\hline \multirow{2}{*}{5} & Control & $26.67 \pm 2.88 \mathrm{a}$ & - \\
\multirow{2}{*}{10} & Vaccine & $8.33 \pm 2.88 \mathrm{~b}$ & $67.76 \pm 13.45$ \\
& Control & $76.66 \pm 23.09 \mathrm{a}$ & - \\
\multirow{2}{*}{15} & Vaccine & $8.33 \pm 2.88 \mathrm{~b}$ & $82.66 \pm 2.30$ \\
& Control & $46.66 \pm 5.77 \mathrm{a}$ & - \\
& Vaccine & $13.33 \pm 2.88 \mathrm{~b}$ & $71.66 \pm 2.88$ \\
\hline
\end{tabular}

Note: similar letter following mean values within the same column and juvenile age indicate significant differences $(\mathrm{P}<0.05)$ among treatments.

Table 3. Average antibody titer in egg and juvenile (5, 10, and 15 days old) catfish

\begin{tabular}{|c|c|c|}
\hline \multirow{2}{*}{ Stage } & \multicolumn{2}{|c|}{ Antibody titer value $(-\log 2)$} \\
\hline & Control & Vaccinated broodstock \\
\hline Eggs & $2.66 \pm 0.57 \mathrm{a}$ & $4.33 \pm 0.57 \mathrm{~b}$ \\
\hline 5 days juvenile & $2.66 \pm 0.57 \mathrm{a}$ & $4.33 \pm 0.57 \mathrm{~b}$ \\
\hline 10 days juvenile & $2.33 \pm 0.57 \mathrm{a}$ & $3.66 \pm 0.57 b$ \\
\hline 15 days juvenile & $2.00 \pm 0.00 \mathrm{a}$ & $3.33 \pm 0.57 b$ \\
\hline
\end{tabular}

Note: similar letter following mean values within the same row indicate significant differences $(\mathrm{P}<0.05)$ among treatments.

The low haemoglobin level in both control and vaccinated broodstock was due to factors that affected its level such as species, broodstock differences (genetic), nutritional condition, physical activities, and age of the fish (Wintoko et $a l ., 2013)$. In addition to haemoglobin, hematocrit is a parameter that also displays erythrocyte level in blood. Determination through hematocrit method was the best method compared to others (total erythrocyte and haemoglobin level) in terms of displaying erythrocyte level in the blood.

Fish hematocrit level varies according to nutritional factors and fish age. A well fed juvenile fish possesses a high hematocrit level compared to under fed juvenile. Data on average broodstock hematocrit level ranged between 29.44-29.93\% (Table 1) and no significant differences among treatments were noticed $(\mathrm{P}>0.05)$. Hematocrit level was still within the normal range for healthy catfish i.e. 30.8-45.5\% (Dopongtonung, 2008).

A decrease in hematocrit level of vaccinated fish showed that a physiological change was caused by the vaccine in the fish body, indicating that the given vaccine had a positive impact on increasing total leukocyte in the fish body (Wintoko et al., 2013). According to Jawad et al. (2004), hematocrit level of fish is high at the beginning of the maturation and decreases 
during the spawning process (increase again after spawning). Thus, it could be concluded that broodstock vaccination does not significantly affect the changes in blood profile such as total erythrocyte, hematocrit level, and haemoglobin level of broodstock.

Total leukocyte in the blood showed the health condition of the fish. Fish exposed to stress caused by environmental changes or extraneous factors showed an increase in total leukocyte cell as reponse to stress. Data on average total leukocyte observed in the present study ranged between $3.30-5.13 \times 10^{4} \mathrm{cell} / \mathrm{mm}^{3}$ (Table 1) and resulted in no significant differences among treatments $(\mathrm{P}<0.05)$. However, an increase in total leukocyte occurred in broodstock after vaccination $\left(5.13 \times 10^{4}\right.$ cell $\left./ \mathrm{mm}^{3}\right)$, exhibiting that vaccine is able to increase the cellular defensive response by mean of increasing total leukocyte of the broodstock. The mentioned increase is related to the function of white blood cell (WBC) as a defense tool. According to Purwanti et al. (2014) the increase in leukocyte concentration positively affects antibody formation, leading to body resistance response against extraneous substance.

Total leukocyte is also used as a marker of pathogenic infection in the body, causing the body to produce more leukocyte. In the present case, increasing total leukocyte as a result of vaccine can indirectly increase natural immune response which is marked by an increase in phagocytic cells. Phagocytic cells have a correlation with antibody titer test that was performed i.e. phagocytic cells operating as antigen recognizer or vaccine that is injected into the fish body (Wintoko et al., 2013).

In the present study, spawning was performed four weeks post-vaccination so that the formed antibody could be transferred to offspring through yolk egg during vittelogenesis (Swain \& Nayak, 2009). Antibody test observed in broodstock before vaccination was 3.00 (Table 1), and increased up to 5.66 after broodstock vaccination $(\mathrm{P}<0.05)$ or showed a value that significantly differed compared to control. There were agglutination reaction in the fish body that occured in broodstock before vaccination and were caused by the presence of natural antibody in the fish. It could be also due to the rearing environment of the broodstock which was an open pond, resulting in a contact between fish and a pathogenic agent in the pond environment, causing natural antibody effects (Firdausi, 2014). Meanwhile, the increase of antibody titer test value in broodstock after vaccination is believed to be a consequence of broodstock vaccination that was able to induce antibody formation in the fish body.

A challenge test was performed on juvenile resistance against pathogenic agent in order to determine the efficacy and potential of broodstock vaccination in juvenile protection. The system used was similar to natural exposure, in doing so, the challenge test was carried by mean of immersion with a bacterial concentration of 106 $\mathrm{cfu} / \mathrm{mL}$. Data on mortality rate (MR) of 5,10 , and 15 days old juvenile obtained post-challenge test ranged between $8.33-76.66 \%$ (Table 2). In general, MR was lower in vaccinated juvenile $(\mathrm{P}<0.05)$ compared to control, proving that vaccination is able to decrease mortality rate (at juvenile stage) caused by $A$. hydrophila bacteria. Similar results were reported in previous research as well and showed a decrease in MR of juvenile resulting from vaccinated broodstock that were infected by intact $S$. agalactiae cell (Firdausi, 2014).

RPS data post-challenge test of juvenile ranged between $67.76-82.66 \%$ (Table 2), showing that 5 days old juvenile had RPS value that were lower compared to the 10 and 15 days old juvenile. The mentioned event was due to the fact that there was a high mortality chance at the beginning of the rearing, which was a consequence of immune response organ, also known as limfomieloid organ such as thymus, front kidney, and spleen, that were not yet ready to produce antibody (Magnadottir et al., 2005). However, Juvenile RPS was generally higher (above 60\%), indicating that broodstock vaccination can increase juvenile reistance against pathogenic infection. Several research demonstrated that broodstock antibody could be transferred to offspring and become the best protection (Wang et al., 2012; Nisaa et al., 2016).

Antibody titer was observed in eggs and 5, 10, and 15 days old juvenile catfish, and the observation was carried out in eggs to prove that antibody entered the egss, and the data ranged between 2.66-4.33 (Table 3), which were significantly different among treatments. The antibody titer was higher in vaccinated broodstock eggs compared to control and was believed to be a result of antibody transfer from broodstock to egg. Antibody that is formed and released could be found in broodstock serum that flows in the blood stream (Swain \& Nayak, 2009).

Mulia and Purbomartono (2007) stated that vaccine effectiveness in overcoming MAS 
(motile aeromonad septicemia) disease in catfish (lele dumbo) is influenced by the vaccine type or the bacterial cell that is used as vaccine. Maternal immunity transfer engineering through broodstock vaccination is an effort to anticipate high mortality in offspring when they are below a month old (Mingming et al., 2014). According to Grindstaff (2008), maternal antibody from broodstock can decrease the mortality risks during juvenile developmental stages.

Antibody titer of juvenile fish ranged between 2.00-4.33, where the highest titer was noticed in five days old juvenile, and gradually decreased in 10 and 15 days old juvenile (Table 3 ). However, juvenile from vaccinated broodstock had higher antibody titer $(\mathrm{P}<0.05)$ compared to control treatments. Indeed, Nur et al. (2004) stated that antibody titer level of broodstock transferred to juvenile would gradually decrease in relation to the age of juvenile. Zhang et al. (2013) explained that specific antibody that is transferred through broodstock naturally follows the metabolism along with the yolk egg.

\section{CONCLUSION}

Catfish broodstock vaccination can lead to maternal immunity transfer (antibody) to juvenile. Juvenile protection level from vaccinated broodstock against Aeromonas hydrophila infection resulted in relative percent survival of 5,10 , and 15 days old juvenile i.e. $67.76 \%, 82.66 \%$, and $71.66 \%$.

\section{REFERENCES}

Azhar F. 2013. The effects of probiotic and prebiotic on performance of juvenile polkadot gouper Cromileptes altivelis. Buletin Veteriner Udayana 6: 1-9.

Dopongtonung. 2008. Gambaran darah ikan lele Clarias sp. yang berasal dari daerah LaladonBogor [Skripsi]. Bogor: Institut Pertanian Bogor.

Fernandez JB, Yambot AV, Almeria O. 2014. Vaccination of nile tilapia Oreochromis niloticus using lipopolysaccharide (LPS) prepared from Aeromonas hydrophila. International Journal of Fauna and Biological Studies 1: 1-3.

Firdausi PA. 2014. Whole cell vaccination of the red strain Nile tilapia broodstock and it's offspring resistance against Streptococcus agalactiae [Skripsi]. Bogor (ID): Institut
Pertanian Bogor.

Fu GH, Liu F, Xia JH, Yue GH. 2014. The LBP gene and its association with resistance to Aeromonas hydrophila in tilapia. International Journal of Molecular Sciences 15: 22.02822.041 .

Ghenghesh SK, Ahmed F, El-Khalek AR, Al-Gendy A, Klena J. 2008. AeromonasAssociated infections in developing countries. Journal of Infection in Developing Countries 2: 81-98.

Gudding R, Willem B, Muiswinkel V. 2013. A history of fish vaccination science-based disease prevention in aquaculture. Fish and Shellfish Immunology 30: 1-6.

Grindstaff JL. 2008. Maternal antibodies reduce costs of an immune response during development. Journal of Experimental Biology 211: 654-660.

Hidayatullah D. 2016. Efficacy of Streptococcus agalactiae re-vaccine on tilapia broodstock to maternal immunity in preventing streptococcosis [Thesis]. Bogor (ID): Institut Pertanian Bogor.

Jawad AL, Al-Mukhtar AM, Ahmed KH. 2004. The relationship between hematocrit and some biological parameters of the Indian shad, Tenualosa ilisha (Family Clupeidae). Animal Biodiversity and Conservation 27: 47-52.

Magnadottir B, Lange S, Gudmundsdottir S, Bogwald J, Dalm RA. 2005. Ontogeny of humoral immune parameters in fish. Fish dan Shellfish Immunology 19: 429-439.

Mingming H, FuHong D, Zhen M, Jilin L. 2014. The effect of vaccinating turbot broodstocks on the maternal immunity transfer to offspring immunity. Fish and Shellfish Immunology 30: $1-7$.

Mulia SD, Purbomartono C. 2007. Efficacy comparison of intra and ekstracellular products vaccine if Aeromonas hydrophila to control motil aeromonas septicaemia (MAS) in catfish Clarias sp. Jurnal Perikanan 9: 173-181.

Nisaa K, Sukenda S, Junior MZ, Lusiastuti AM, Nuryati S. 2016. Resistance of tilapia Ooreochrimis niloticus fry vaccinated at different gonadal developmental stages toward Streptococcus agalactiae infection. Jurnal Veteriner 17: 355-364.

Nur I, Sukenda, Darna D. 2004. Resistance of fry from vaccinated mother of gift tilapia Oreochromis niloticus Linn. to artificial infection of Streptococcus iniae. Jurnal Akuakultur Indonesia 3: 37-43. 
Pramudita, Sarjito, Prayitno BS. 2013. Identification of agents bacteria causing motile aeromonas on dumbo catfish Clarias gariepinus from Rowosari Subdistrict, Kendal District. Journal of Aquaculture Management and Technology 2: 1-9.

Purwanti CS, Suminto, Sudaryono A. 2014. The description of blood profile catfish Clarias gariepinus that is fed with a combination of artificial feed and earthworm Lumbricus rubellus. Journal of Aquaculture Management and Technology 3: 53-60.

Sayed AEH, Moneeb RH. 2015. Hematological and biochemical characters of monosex tilapia Oreochromis niloticus Linnaeus 1758 cultivated using methyltestosterone. The Journal of Basic and Applied Zoology 72: 36-42.

Sugiani D, Sukenda, Enang Harris, Lusiastuti AM. 2013. Vaccination of tilapia Oreochromis niloticus using monovalent and bivalent vaccines for motile aeromonas septicemia and streptococcosis disease. Jurnal Riset Akuakultur 8: 230-239.

Swain P, Nayak SK. 2009. Role of maternally derived immunity in fish. Fish and Shellfish Immunology 27: 89-99.
Wahjuningrum D, Solikhah HE, Budiardi T, Setiawati M. 2010. Infection control of Aeromonas hydrophila in catfish Clarias sp. using mixture of meniran Phyllanthus niruri and garlic Allium sativum in feed. Jurnal Akuakultur Indonesia. 9: 93-103.

Wang H, Ji D, Shao J, Zhang S. 2012. Maternal transfer and protective role of antibodies in zebrafish Danio rerio. Molecular Immunology 51: 332-336.

Wintoko F, Setyawan A, Hudaidah S, Ali M. 2013. Imunogenisitas heat killed vaksin inaktif Aeromonas hydrophila pada ikan mas Cyprinus carpio. Jurnal Rekayasa dan Teknologi Budidaya Perairan 2: 205-210.

Yi T, Li WY, Liu L, Xiao XX, Li AX. 2014. Protection of nile tilapia Oreochromis niloticus L. against Streptococcus agalactiae following immunization with recombinant FbsA and

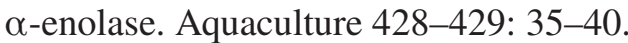

Zapata A, Díez B, Cejalvo T, Gutiérrez-de CF, Cortés A. 2006. Ontogeny of the immune system of fish. Fish and Shellfish Immunology. 20: $126-136$.

Zhang S, Wang Z, Wang H. 2013. Maternal immunity in fish: Review. Developmental and Comparative Immunology 39: 72-78. 